\title{
Using State Pension Shocks to Estimate Fiscal Multipliers since the Great Recession
}

\author{
By Daniel Shoag*
}

* Shoag: Harvard Kennedy School, 79 JFK Street, Cambridge, MA 02138 (e-mail: dan_shoag@hks.harvard.edu).

One painful lesson from the Great Recession is that there remain limits to what is achievable with conventional monetary policy. The severity of the downturn, despite near zero interest rates, has renewed interest in fiscal stimulus among academics and policy makers alike. Holding the general question of fiscal multipliers aside, the ongoing political debate regarding past and future stimulus raises the pressing question of the current size of the multiplier in the United States. This paper aims to provide evidence on that question. Has government spending raised income and employment since 2008?

The canonical literature estimating fiscal policy multipliers uses either time-series models (Blanchard and Perotti 2002) or variation in national defense spending due to exogenous military events (Barro and Redlick 2011, Ramey 2011). In recent years there have been a number of studies estimating fiscal policy multipliers at the regional level using an instrumental variables approach. For example, Nakamura and Steinsson (2011) isolate variation in local military spending due to changes in national defense outlays, and Serratto and Wingender (2010) estimate the effect of spending due to Census over- and undercounting. These studies, as well as several others ${ }^{1}$, generally find that exogenous spending shocks have significant and sizeable income and employment effects.

The identification strategies used in most of these papers are not easily adapted to study the specific effects of spending in the US since 2008. A number of papers, such as Sacerdote (2011), Chodow-Reich et al. (2012), and Wilson (2012), have estimated fiscal multipliers in this recession using local variation in ARRA stimulus outlays. Like the regional-level literature discussed above, these papers generally find that spending increased both local income and employment. The importance of the question, though, warrants investigation using an additional, independent source of variation.

In this paper, I exploit the identification strategy used in Shoag (2010) to recover exogenous spending changes associated with

\footnotetext{
${ }^{1}$ See Acconcia et al (2011), Clemens and Miran (2012), Fishback and Kachanovskaya (2010), and Reingewertz (2011) for additional work on this topic. Cohen et al. (2011) finds negative effects at the firm level.
} 
the investment returns earned by public pension plans. This work builds upon that study by examining new data on pension returns during the Great Recession and by estimating multipliers specifically for the post2008 period.

Relative pension returns are a suitable instrument because they are unexpected and plausibly uncorrelated with underlying regional shocks. The strategy is particularly attractive in this context due to the volatile investment returns earned by public plans in 2008-09. While this strategy can be used to estimate multipliers in the years after 2008, these results should nevertheless be interpreted with caution due to the short panel and the specification sensitivities that engenders.

That said, using this strategy I too find that windfall-financed spending significantly raises local incomes and employment. The baseline estimates, using only data on returns during the volatile fiscal years of 2008 and 2009, suggest that each dollar of spending raises instate income in that year by $\$ 1.43$, or more than one-for-one. This estimate is well within the confidence interval of the multiplier documented in Shoag (2010), despite the nonoverlapping data sets. Further, I estimate that every additional $\$ 22,011$ of spending contemporaneously creates one job. Unlike in
Shoag (2010), the bulk of the employment response during the Great Recession is generated by reducing the number of unemployed, rather than by drawing nonparticipants into the labor force.

\section{State and Local Pensions}

In 2010, state and local governments managed over $\$ 3$ trillion in public employee retirement trust funds, a significant figure relative to total annual spending of $\$ 3.1$ trillion. The vast majority of these funds are held for defined benefit plans, meaning these governments are the residual claimants on the investment returns. ${ }^{2}$ These investment returns have historically been a major source of revenue for state and local governments. Shoag (2012) calculates that public pensions have generated $\$ 3.73$ trillion in returns between 1958 and 2010. For the average state, these earnings have equaled $15 \%$ of total state and local tax collection over this period.

Between the second quarter of 2007 and the second quarter of 2009, public pension trust funds fell by more than $\$ 735$ billion. These losses, combined with stalled tax revenues, have put a large burden on state and local government. Contributions into public pension

\footnotetext{
2 Farrell and Shoag (2012) document the growing shift away from DB plans in the public sector and discuss its implications for the management of these assets.
} 
funds rose by more than $40 \%$ from 2006 to 2011. In contrast, state tax collections have risen only $6 \%$ over that time. In this paper, I use data on the returns earned by plans in 2008 and 2009, when many plans experienced sharp investment losses, to isolate exogenous budgetary pressure and spending changes.

\section{Data}

The data for state-administered plans are from the Pensions and Investments Public 100: Top DB Plans database. These data are collected from audited financial reports published or directly from the plans themselves. In total, there are 91 statewide plans with available data. One attractive feature of this dataset is that it collects planspecific benchmark returns, asset class performance, and asset allocations for most systems. In order to maintain a complete sample, I created synthetic benchmarks ${ }^{3}$ for the plans that did not report a policy return using those systems' reported allocations and the average within-class returns of the reporting plans.

\footnotetext{
3 This was possible for all but one plan, for which a benchmark was created using its own reported asset class benchmarks, the Cambridge Associates Private Equity Index, and MSCI US REIT Index Returns.
}

Data on state-level spending, income, and employment are taken from standard sources. ${ }^{4}$

\section{Specifications and Findings}

The variation in the investment returns earned by public plans can be decomposed into the variation in asset-class allocations and variation in within asset-class performance. While asset-class allocations are not distributed randomly, Shoag (2010) shows that for the purposes here, the variation in within-class returns is unrelated to a state's underlying economic shocks. ${ }^{5}$ Thus I define the pension return shock in per capita terms as:

ExFunds $_{i t}=\sum_{p \in \text { plans }_{i}} \frac{\left(r_{i p t}-\bar{r}_{i p t}\right) \times \text { Assets }_{i p t-1}}{\text { Pop }_{i t}}$

or the sum of the excess funds for all plans managed by the state, where $r_{i p t}$ is the return earned by a plan and $\bar{r}_{i p t}$ is the corresponding benchmark return. Figure 1 plots the distribution of investment returns in excess of policy benchmarks in 2008 and 2009.

\footnotetext{
4 Additionally, I use government spending data from the Census State Government Finances Series, data on state level employment and unemployment from the BLS Current Employment Statistics (CES) and Local Area Unemployment Statistics (LAU), and data on personal income from the BEA Regional Economic Accounts.

5 A number of papers explore the amount of in-state bias in public pension plan investments, including Brown, Pollet, and Weisbenner (2009), Munnell and Sunden (2001), and Hochberg and Rauh (2011). Calculations in Shoag (2010) show that the magnitude of this bias is sufficiently small relative to the variability of return that, for this application, it does not in practice violate the exclusion restriction.
} 


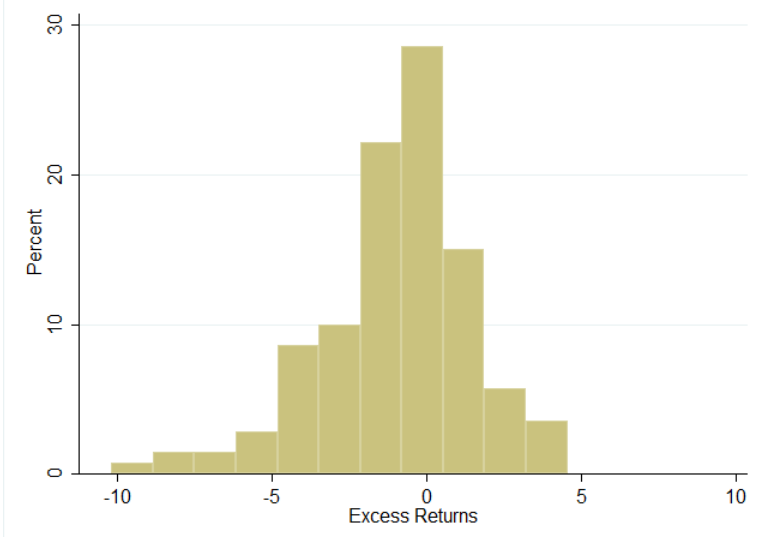

FIGURE1. DISTRIBUTION OF PLAN EXCESS RETURNS, JUNE FY08 \& FY09 NOTE: ADDITIONAL DETAILS ARE PROVIDED IN THE TEXT.

A Shapiro-Wilk test fails to reject the normality of the distribution in 2008 at the $5 \%$ level, and with the exclusion of a single noninfluential outlier, fails to reject the normality of the distribution in 2009. Further, the correlation between a plan's excess return in 2008 and 2009 is just 0.08 and not significant.

Again, following Shoag (2010), I model the response of state government spending to this shock as beginning in the following fiscal year. In the interests of obtaining sufficiently precise results in a short panel, I use a first difference specification with year fixed effects. The results are moderately sensitive to the specification choices. The variables are in per capita terms, the regressions are weighted by population, and the standard errors are clustered by state. Time observations correspond to fiscal years. ${ }^{6}$

\footnotetext{
6 Occasionally, the fiscal year for a pension plan will end after the fiscal year of the administering state. In these cases I attribute the excess funds to following year, so that all excess fund shocks are lagged by at least 12 months and no more than 21 months
}

The first-stage regression takes the form:

$$
\Delta g_{i t}=\alpha_{t}+\beta \times \text { ExFunds }_{i t-1}+\varepsilon_{i t}
$$

with the second stage taking the form:

$$
\Delta y_{i t}=\alpha_{t}+\beta \times \widehat{\Delta g}_{\imath t}+\epsilon_{i t}
$$

with only the variation in spending associated with the excess funds shocks appearing on the right-hand side. The outcome variables $\Delta y_{i t}$ in equation (3) include per capita income and labor market outcomes.

\section{Results}

The main results are presented in Table 1. The first stage estimates, displayed in Column 1, show that an excess funds shock significantly affects state government spending in the following year. A \$1 increase in excess funds increases spending by $\$ 0.29$. As in Shoag (2010), this is a large effect, and the interpretations discussed there are relevant here. Unreported placebo tests show that future windfalls do not predict past spending changes,

Table 1- Baseline Results

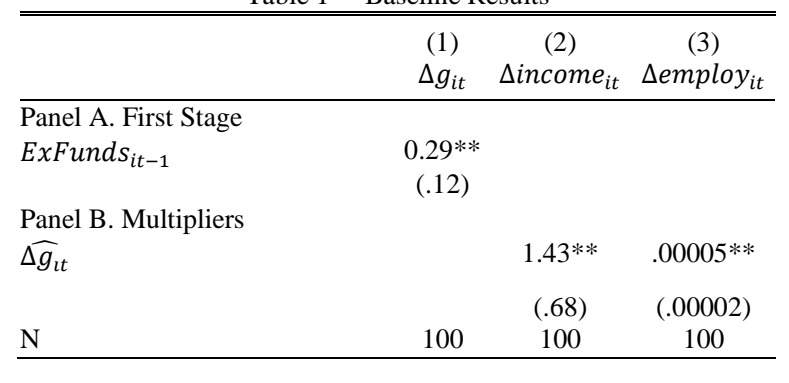

Notes: All regressions include a year fixed effect. The variables are measured in per capita terms, the regressions are weighted by population, and the standard errors are clustered by state. Details on the variables are included in the text. 
Column 2 reports the baseline income multiplier: a \$1 increase in windfall driven spending increases in-state per capita income by $\$ 1.43$. This estimate is significant and similar both to the estimates in Shoag (2010) and to the range of estimates produced in the literature described above. Colum 3, which uses data from the BLS-CES, indicates that an additional $\$ 100,000$ of spending adds an additional 4.5 jobs.

In Table 2, I use data from the BLS-LAU to explore the source of these additional jobs.

\begin{tabular}{lccc}
\multicolumn{4}{c}{ Table 2- Dollars Per Labor Market Outcome } \\
\hline \hline & $\begin{array}{c}(1) \\
\Delta e m p l o y_{i t}\end{array}$ & $\begin{array}{c}(2) \\
\text { Dunemploy }\end{array}$ & $\begin{array}{c}(3) \\
\text { sparticit }\end{array}$ \\
\hline Dollars per & $4.82^{*}$ & $-2.52^{* * *}$ & 2.31 \\
$\widehat{\Delta g}_{t t} \times 100,000$ & $(2.70)$ & $(.96)$ & $(2.24)$ \\
$\mathrm{N}$ & 100 & 100 & 100 \\
\hline
\end{tabular}

Notes: All regressions include a year fixed effect. The variables are measured in per capita terms, the regressions are weighted by population, and the standard errors are clustered by state. Details on the variables are included in the text.

These data, with spending now measured in $\$ 100,000$ units, indicate similar overall employment increases. Unlike Shoag (2010), where the majority of the gains stemmed from increased participation, a significant portion of the increase in this period arises from reductions in unemployment. This is an intriguing finding, and more work is needed to determine what underlies this difference.

\section{Conclusion}

This study, like much of the literature cited above, finds that local, windfall-financed government spending has large employment and income effects. Despite using entirely new data, the estimates closely match those in Shoag (2010). While these results should be interpreted cautiously, the mounting evidence from a number of different studies on local, windfall multipliers suggests a growing consensus on this issue, both generally and post-2008. If this holds as more evidence arrives, this is an important result for macroeconomic theory.

The policy implications of these findings, however, need to be parsed carefully. Farhi and Werning (2012) demonstrate that large local, windfall-financed multipliers in a new Keynesian model do not imply large multipliers in other contexts, and Mankiw and Weinzierl (2011) note that policies with larger multipliers may not lead to larger welfare increases. Thus the empirical evidence on multipliers should be used in conjunction with macroeconomic models when evaluating the desirability of fiscal stimulus. 


\section{REFERENCES}

Acconcia, Antonio, Giancarlo Corsetti, and Saverio Simonelli. "Mafia and public spending: Evidence on the fiscal multiplier from a quasi-experiment." mimeo, (2011).

Barro, Robert , and Charles Redlick. "Macroeconomic effects from government purchases and taxes." The Quarterly Journal of Economics 126.1 (2011): 51-102.

Blanchard, Olivier, and Roberto Perotti. "An empirical characterization of the dynamic effects of changes in government spending and taxes on output." the Quarterly Journal of economics 117.4 (2002): 1329-1368.

Brown, Jeffrey, Joshua Pollet, and Scott Weisbenner. "The investment behavior of state pension plans". mimeo, (2009)

Chodorow-Reich, Gabriel, et al. "Does state fiscal relief during recessions increase employment? Evidence from the American Recovery and Reinvestment Act." American Economic Journal: Economic Policy 4.3 (2012): 118-145.

Clemens, Jeffrey, and Stephen Miran. "Fiscal Policy Multipliers on Subnational Government Spending." American Economic Journal: Economic Policy 4.2 (2012): 46-68.

Cohen, Lauren, Joshua Coval, and Christopher Malloy. "Do Powerful Politicians Cause Corporate Downsizing?" Journal of
Political Economy 119, no. 6 (December 2011): $1015-1060$

Farhi, Emmanuel, and Iván Werning. "Fiscal Multipliers: Liquidity Traps and Currency Unions.” mimeo, 2012.

Farrell, James and Daniel Shoag. "Asset Management in Public DB and Non-DB Pension Plans" mimeo, (2012).

Feyrer, James, and Bruce Sacerdote. "Did the stimulus stimulate? Real time estimates of the effects of the American Recovery and Reinvestment Act." mimeo, 2011.

Fishback, Price, and Valentina Kachanovskaya. "In Search of the Multiplier for Federal Spending in the States during the New Deal." mimeo, 2010.

Hochberg, Yael, and Joshua Rauh. "Local overweighting and underperformance: evidence from limited partner private equity investments. mimeo, 2011.

Mankiw, N. Gregory, and Matthew Weinzierl. "An Exploration of Optimal Stabilization Policy" Brookings Papers on Economic Activity (spring 2011).

Munnell, Alicia and Annika Sundén "Investment Practices of State and Local Pension Plans." in Olivia S. Mitchell and Edwin C. Hustead, eds., Pensions in the Public Sector. The Pension Research Council and University of Pennsylvania Press (2001) 
Nakamura, Emi, and Jon Steinsson. "Fiscal stimulus in a monetary union: Evidence from US regions." mimeo 2011.

Ramey, Valerie A. "Identifying Government Spending Shocks: It's all in the Timing." The Quarterly Journal of Economics 126.1 (2011): $1-50$.

Reingewertz, Yaniv. "Identifying the Effect of Government Spending: Evidence from Political Variations in Federal Grants." mimeo (2011).

Serrato, Juan Carlos Suárez, and Philippe Wingender. "Estimating local fiscal multipliers." mimeo (2010).

Shoag, Daniel. "The impact of government spending shocks: Evidence on the multiplier from state pension plan returns." mimeo (2010).

Shoag, Daniel. "States and Risky Investments: Understanding Public Pension Plans" mimeo (2012).

Wilson, Daniel J. "Fiscal Spending Jobs Multipliers: Evidence from the 2009 American Recovery and Reinvestment Act." American Economic Journal: Economic Policy 4.3 (2012): 251-282. 